Business and Management

Year: 2017 Volume: 4 Issue: 3

\title{
IMPACT OF MARKETING AND R\&D EXPENDITURES ON FINANCIAL PERFORMANCE: A RESEARCH IN MANUFACTURING INDUSTRY
}

\author{
DOI: 10.17261/Pressacademia.2017.713 \\ RJBM- V.4-ISS.3-2017(12)-p.359-371
}

Mehmet Caglar* ${ }^{1}$, Rauf Nurettin Nisel ${ }^{2}$

${ }^{* 1}$ Yıldız Technical University, Department of Business Administration, i̇stanbul, Turkey. mcaglar@yildiz.edu.tr

${ }^{2}$ Marmara University, Department of Business Administration, İstanbul, Turkey. rnisel@marmara.edu.tr

To cite this document

Caglar, M. and R.N.Nisel, (2017). Impact of marketing and R\&D expenditures on financial performance: a research in manufacturing industry. Research Journal of Business and Management (RJBM), V.4, Iss.3, p.359-371.

Permemant link to this document: http://doi.org/10.17261/Pressacademia.2017.713

Copyright: Published by PressAcademia and limited licenced re-use rights only.

\begin{abstract}
Purpose- In this research it is aimed to investigate the impact of marketing and research and development (R\&D) expenditures of companies on their financial performance in manufacturing industry.

Methodology- Data of 41 manufacturing companies listed on Borsa İstanbul (BIST) was gathered for the period of 2009-2015 from their financial statements. Since the data set is a panel data, methods of panel regression analysis have been performed.

Findings- As a result of the analysis, impact of marketing and R\&D expenditures on firms' performance differentiate according to financial performance measures and it is founded that they have no effect on some financial performance indicators.

Conclusion- Test results imply that marketing and R\&D expenditures have positive contribution to manufacturing companies' some of the financial performance indicators. However, manufacturing companies cannot use marketing and R\&D budgets in an effective and efficient way. Manufacturing companies are not able to manage marketing and R\&D activities successfully.
\end{abstract}

Keywords: Marketing expenditures, research and development expenditures, panel data analysis, financial performance, JEL Codes: M31, O32, C23

\section{INTRODUCTION}

As competition between businesses increases, it gets harder to survive and grow in the industry. In order to maintain a sustainable development, companies try to increase their profit, business value, and financial performance as much as possible with their limited resources. In this regard, deployment and effective usage of resources are key factors for companies to reach their business goals. Effective allocation and usage of resources leads businesses to success and it is a key for financial performance and competitive advantage.

In order to gain a sustainable competitive advantage and increase business value, organizations try to add value to their brands, goods and services, and they exert effort to improve the quality of their products, services and processes. These efforts address two major activities of organizations: "Marketing" and "Research and Development". To keep in touch with their current customers, to reach potential customers and to increase their recognition they spend huge amount of money on marketing activities. In order to produce better products and offer better services, they spend time and money on research and development activities. The final goal of these activities is to increase financial performance and business value.

In this research it is aimed to investigate the impact of marketing and research and development (R\&D) expenditures of manufacturing companies on their financial performance. To evaluate financial performance some performance indicators which are related to marketing and R\&D expenditures are selected. In this research selected financial performance indicators are revenue, gross profit, earnings before interest and tax (EBIT), net income, gross profit margin (GPM), and return on sales (ROS). The impact of marketing and research and development expenditures on the selected financial performance indicators will be examined separately. 
In this paper firstly the literature about impact of marketing and R\&D expenditures on financial performance will be summarized. After literature review, research model and the variables in the research model will be explained. The target population, data and methodology will be clarified. In findings and discussions part the results of the analysis will be discussed. At the end, the conclusion of the research will be expressed.

\section{LITERATURE REVIEW}

Marketing and Research and Development activities are two main operations of manufacturing companies. Marketing and R\&D activities are very important functions for firms to survive and grow in the industry. In the fierce competitive business environment it is inevitable to focus on these functions. All the firms have to focus on marketing activities to increase their market sensing capabilities which includes understanding customers' needs, wants and demands, building long-term relationship with customers.

Marketing and R\&D expenditures are viewed as intermediate assets between marketing activities and firm-level financial performance (e.g., Ramaswami et al. 2009). Financial performance could be achieved in many ways, yet achieving continuous and sustainable financial performance could be ensured through market-based assets. According to Srinivasan and Hanssens (2009) marketing activities create market-based assets, which ultimately enhance financial performance of companies. Some of market-based assets are brand equity, channel equity, customer satisfaction, customer loyalty, company reputation, brand reputation and perceived product quality (Aaker and Jacobson, 1994; Sharp, 1996; Srivastava et al., 1998; Srinivasan and Hanssens, 2009). These market based assets are believed to influence intermediate outcomes of firms such as customer thoughts, feelings, knowledge, and behavior (O'Sullivan \& Abela, 2007). To create market-based assets firms spend effort and money resources on their marketing activities. However marketing activities may not be enough to gain and sustain these intangible assets. Brand equity, brand awareness and market-sensing capability could be achieved through successful marketing activities. Providing customers with high-quality goods, services, and processes with a reasonable price will increase customer loyalty and customer satisfaction. Besides successful marketing activities, firms need to have effective research and development activities. Once these activities and strategies are implemented successfully, firms can increase their profit. It is obvious that proper fit of marketing and R\&D activities lead to sustainable competitive advantage and financial performance.

Marketing capability is defined as the integrative process which includes understanding consumers' specific needs, achieving product differentiation and superior brand equity (Day, 1994; Dutta et al., 1999; Song et al., 2005, Song et al., 2007; Yu et al., 2014). Vorhies and Morgan (2003; 2005) stated that marketing capability is related to business performance and firms can enhance their financial performance by improving their marketing capability. Besides this, according to Nath et al. (2010) marketing capability is one of the most important sources of competitive advantage. Thus, marketing activities are very crucial functions for firms to focus on in order to achieve competitive advantage and business performance.

Marketing capability helps a company in building and maintaining long-term relationships with customers and channel members (Song et al., 2007). Ortega and Villaverda (2008) argued that marketing capability creates a strong brand image for the firms which allows them to achieve superior business performance. Therefore, companies devote efforts and resources in order to enhance their market sensing capabilities (Narsimhan et al., 2006). Increased marketing capabilities ultimately would increase firms' business performance. In marketing literature, many studies have found that there is a significant relationship between marketing capability and financial performance (Dutta et al., 1999; Nath et al., 2010; Song et al., 2005; Vorhies \& Morgan, 2005).

Superior customer value can be achieved through customer intimacy and product leadership which are result of marketing and R\&D capabilities (Treacy \& Wiersema, 1993; Krasnikov \& Jayachandran, 2008). Thus, marketing and R\&D activities are main functions to develop and implement a strategy for sustainable competitive advantage and business performance.

Firms' ability to develop and exploit their innovative capabilities is accepted as an important determinant of competitive advantage and performance (Voss, 1994; Bettis and Hitt, 1995; Helfat and Peteraf, 2003). Because of the increasing levels of competition and decreasing product life cycle, a firm's ability to generate a continuous stream of innovations which allows firms to develop and maintain competitive advantage may be more important than ever (Artz et al., 2010). In this regard firms devote efforts and resources in research and development activities more than they use to do.

Firms can provide economic rent, develop their technological capabilities and acquire first-mover advantage by R\&D activities, which of all contribute to firms' performance (Bowen et al., 2010). In fierce competitive business environment, R\&D expenditures can enhance firm performance by reducing production cost and launching new products (Ruiqi et al., 2017). R\&D activities will enhance firms' long-term performance by helping firms to generate new knowledge and widen the scope of firms' knowledge base and improve firms' capability to absorb and integrate existing knowledge (Cohen \& Levinthal, 1989). However, R\&D activities are risky and are not always drivers of superior future performance (Liao \& Rice, 2010). In manufacturing industry product innovation is a crucial part of R\&D activities. In marketing context product innovation is very important since it allows firms to develop new market segments as well as expand their current market 
segments and product portfolios (Gupta et al., 1986; Slotegraaf \& Pauwels, 2008). However, innovative products and services may not actually satisfy market needs (Liao \& Rice, 2010), product innovation may lead to higher costs (Lynn, 1998) and it also may lead higher risks and management challenges (Danneels \& Kleinschmidt, 2001). Newly designed products may cause unexpected manufacturing problems, or may not be commercially viable. R\&D expenditures for new product development may exceed profits gained from these new products, which results R\&D expenditures becoming sunk costs (Hsu et al., 2013). Because of these risks the effect of research on product innovation on firm performance remains unclear (De Luca \& Atuahene-Gima, 2007). Besides their benefits, R\&D expenditures pose risks. Thus, intellectual property produced by R\&D investment must be properly understood and appropriately managed to increase future firm performance (Edvinsson and Malone, 1997).

According to Mizik and Jacobson (2003) superior organizational performance resulting from competitive advantage is the result of a firm's two main capabilities: superior customer-value creation capabilities and value appropriation capabilities. Value creation process is related to research and development activities, while value appropriation process is related to advertising activities (Peterson \& Jeong, 2010). Andras and Srinivasan (2003) stated that marketing and research and development expenditures are two key inputs which should be effectively managed to compete successfully in the market. In the literature there are contradictory results about the incidence of the R\&D expenditures on the firm's financial performance (Lantz \& Sahut, 2005).

To sum up the marketing and research and development literature, to gain sustainable financial performance and competitive advantage, firms must effectively and efficient manage their marketing and R\&D activities.

\section{DATA AND METHODOLOGY}

In this study, it is aimed to investigate the impact of marketing and R\&D expenditures on financial performance. There are many indicators to measure financial performance and we have to select some of these indicators to build a research model. Purpose of marketing and R\&D expenditures will help us in deciding which financial performance indicators should be selected.

According to literature, main purposes of marketing and R\&D activities are to increase some intangible assets such as brand recognition, brand awareness, market-sensing capability, reputation and offer superior goods and services respectively. Undoubtedly, firms devote efforts and resources to achieve superior business performance through increasing sales and profit. "Revenue", "Gross Profit", "Earnings Before Interest and Tax". "Net Income" "Gross Profit Margin" and "Return on Sales" are selected as financial performance indicators since these are main profitability measures and related to marketing and R\&D expenditures.

In this research, selected financial performance indicators are dependent variables in the research model. Independent variables in the model are "Marketing Expenditures" and "Research and Development Expenditures". Besides dependent and independent variables, there is a time dimension in the research model. Yearly data of 41 companies was collected from 2009 to 2015. Thus while constructing the research model we add this time dimension in the model. The research model is given on Figure 1.

Figure 1: Research Model

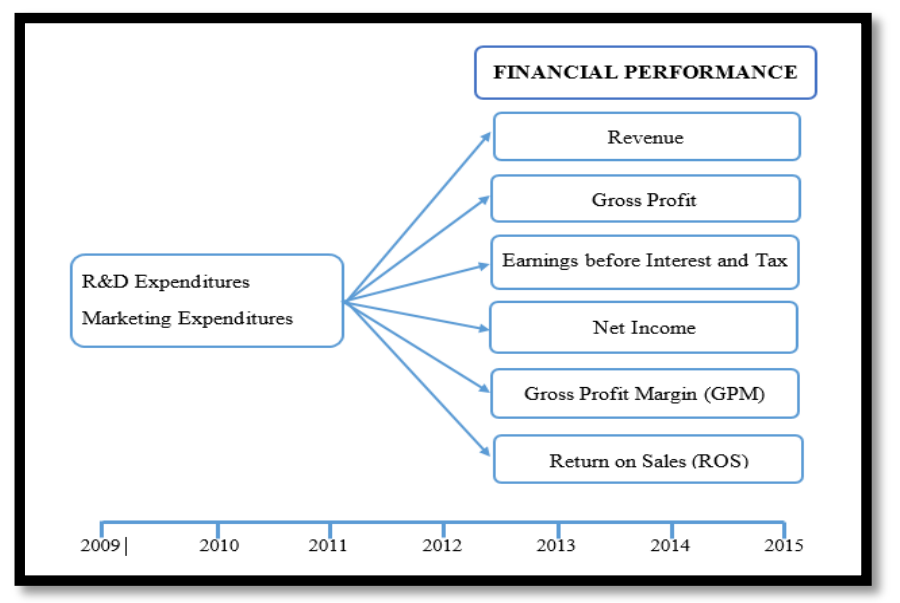

R\&D expenditures are the expenses to run research and development activities. It takes place on an income statement as "Research and Development Expenses" under operating expenses. Marketing expenditures are the general expenses to run 
a company's marketing activities. These expenditures take place on income statements as "Selling, Distribution and Marketing Expenses" which includes and represents all the marketing expenditures.

Revenue is the total amount that firms earned from the sales of goods and services. It is sometimes referred as sales. In manufacturing industry main source of revenue is product sales. Gross Profit is the money amount remaining after deducting cost of goods sold from revenue. EBIT is a measure of a company's profit. It is the difference between operating revenues and operating expenses. It does not include interest and tax expenses. EBIT is given on an income statement. Net Income is the net amount that a firm earns for an accounting period. At the end of a period a firm can have profit or loss, so this value can be either positive or negative. It is computed as deducting all the expenses from all revenues and incomes for an accounting period.

GPM shows what percentage of revenue turns into gross profit. It is not directly given on any financial statements, but it can be calculated by using needed items on an income statement. GPM is calculate as dividing gross profit with revenue. ROS is the measure of effectiveness of a company in transforming sales into profit. It is not directly given on any financial statements, but it can be calculated by using needed items on an income statement. ROS is calculate as dividing EBIT with revenue.

Target population of the research is the manufacturing companies listed on Borsa Istanbul. Marketing activities and related expenditures are inevitable in all the industries. However research and development activities may not be common and sometimes not needed in some industries. For instance, service companies do not focus on R\&D activities, because these firms generally do not need to invest in research and development. R\&D activities are generally needed for product development. For this reason, manufacturing industry is thought to be the most appropriate target population for this research.

The data was gathered from the companies' financial statements. Marketing and R\&D expenditures and some of the financial performance measures are directly given on the financial statements of the companies. Companies' revenue, gross profit, earnings before interest and tax and net income are directly given items on their income statements. Profitability ratios in the model which are gross profit margin and return on sales are calculated by using the necessary data given on the companies' financial statements.

The data was collected from the website of PDP (Public Disclosure Platform). There are 193 manufacturing company listed in Borsa Istanbul at the end of 2015. Only 41 of manufacturing companies have regular and continuous R\&D and marketing expenditures simultaneously since 2009. Since, there were a global crisis in 2008 and it most probably causes a structural break in econometric data we didn't include 2008 and before in the data set. Thus the data of these 41 companies was gathered and examined. The data set consists of two dimensions: unit and time dimensions. Our data set include data from 41 companies over 7 years (2009 to 2015). Since the research data set is a panel data, methods of panel data analysis need to be performed.

\section{FINDINGS AND DISCUSSIONS}

This part is consist of necessary tests performed and the results of these tests. First, unit root test is performed to test whether the variables which will be used in the models are stationary or not. Then all the necessary tests and analysis will be done to see the impact of marketing and research and development expenditures on financial performance. To see the impact of marketing and R\&D expenditures on financial performance, panel regression models will be constructed for each chosen financial performance indicators.

In panel data analysis there are two types of panel unit root tests: first generation and second generation panel unit root tests. If there is cross-section dependence we have to use second generation panel unit root tests, otherwise we can use first generation panel unit root tests. To test cross-section dependence Pesaran (2004) CD test is used. According to CD test there is a cross-section dependence in all the variables since the $p$-value of the test for the all variables are less than 0,05 . This result shows that there is a correlation between cross-section units in the data set. Thus we have to use one of the second generation panel unit root tests.

Among second generation unit root tests, Pesaran's (2003) CADF test is used to test stationarity. Pesaran's (2003) CADF test is performed for all the variables in the data set separately. Results of the CADF test shows that t-bar statistics of all the variables are higher than the critical values for $90 \%, 95 \%$ and $99 \%$ confidence intervals. Test results show that none of the variables contain unit root, in other words all the variables in the data set are stationary. According to this results we can conduct regression analysis by using these variables.

\subsection{Impact of Marketing and R\&D Expenditures on Revenue}

In this part how marketing expenditures and research and development expenditures affect revenue will be examined. The regression model is constructed as follows: 


$$
\text { Revenue }=\beta_{0}+\beta_{1} \text { Marketing Exp. }+\beta_{2} R \& D \text { Exp. }+\varepsilon
$$

In order to decide whether to construct fixed effect or random effect model, Hausman (1978) specification test is performed. Since the $p$ value $(0.4211)$ is higher than $5 \%$, we fail to reject the null hypothesis. This means we can construct FE or RE model. Since RE model is more efficient we will construct a random effect model.

Before interpret the model we have to check assumptions of panel data analysis. We can test heteroscedasticity in panel data analysis with Levene (1960), Brown and Forsythe (1974) tests, since our model is RE. According to the test results, all the $p$ values are less than $5 \%$, thus we reject the null hypothesis. We conclude that, there is a heteroscedasticity problem in the model.

Baltagi-Wu (1999) LBI test, Bhargava, Franzini and Narendranathan (1982) DW-d and Adjusted Lagrange Multiplier (ALM) test can be used to test autocorrelation in the model. When the Baltagi-Wu (1999) LBI test statistic is greater than 2, we cannot reject the null hypothesis and this is what we expect in a regression model. Since Baltagi-Wu (1999) LBI test statistic (1.31) is less than 2 , we reject the null hypothesis. ALM test probability $(0,0283)$ is less than 0.05 , we reject the null hypothesis. Both of the autocorrelation tests state that there is an autocorrelation problem in the model. Pesaran (2004) CDLM and Frees' Q (1995) tests can be used to test cross sectional dependence. Since probability for both of the tests is lower than 0,05 we reject the null hypothesis. We conclude that, there is a cross sectional dependence problem in the model.

We tested the panel data regression assumptions and we failed to satisfy all the assumptions. Thus we have to interpret the regression model with Driscoll-Kraay (1998) robust standard errors. Driscoll-Kraay (1998) standard errors model can be used in the case of existence of heteroscedasticity, autocorrelation and cross-sectional dependence. The interpreted model results are summarized on the table below.

Table 1: Impact of Marketing and R\&D Expenditures on Revenue

\begin{tabular}{|c|c|c|c|c|}
\hline \multicolumn{5}{|c|}{ Regression with Driscoll-Kraay Standard Errors } \\
\hline \multicolumn{2}{|c|}{ Dependent Variable } & \multicolumn{3}{|l|}{ Revenue } \\
\hline \multicolumn{2}{|c|}{ Independent Variables } & \multicolumn{3}{|l|}{ Marketing, R\&D } \\
\hline \multicolumn{2}{|l|}{ Periods } & \multicolumn{3}{|c|}{ 2009-2015 (7 periods) } \\
\hline \multicolumn{2}{|c|}{ Number of Units } & \multicolumn{3}{|l|}{41} \\
\hline \multicolumn{2}{|l|}{ F Statistic } & \multicolumn{3}{|l|}{338.26} \\
\hline \multicolumn{2}{|l|}{ Probability } & \multicolumn{3}{|l|}{0,0000} \\
\hline \multicolumn{2}{|c|}{ R square (overall) } & \multicolumn{3}{|l|}{0.6076} \\
\hline Variable & Coefficient & D-K Std. Err. & t statistic & p-value \\
\hline Constant & $9.23 e+08$ & $1.11 \mathrm{e}+08$ & 8.34 & 0,000 \\
\hline Marketing & 2.771905 & 0.2190208 & 12.66 & 0,000 \\
\hline$R \& D$ & 56.32549 & 2.257792 & 24.95 & 0,000 \\
\hline
\end{tabular}

From the table above we can interpret the regression model. $\mathrm{F}$ statistic and its probability shows that the model is valid. We can explain about $61 \%\left(R^{2}\right)$ of change in revenue with marketing and R\&D expenditures. The explanatory power of the model is high enough. All the independent variables are significantly affect the dependent variable.

There is a positive impact of marketing and R\&D expenditures on firms' revenue. 1 TL increase in marketing, increases revenue about 2,77 TL. 1 TL increase in R\&D, increases revenue about 56,32 TL. The impact of R\&D is way higher than the impact of marketing on revenue in manufacturing industry. This results show that increasing revenue is highly affected by R\&D expenditures. In manufacturing sector, the firms which place a particular importance to R\&D activities and try to increase their product and service quality will easily increase their sales.

\subsection{Impact of Marketing and R\&D Expenditures on Gross Profit}

In this part impact of marketing expenditures and research and development expenditures on gross profit will be examined. The regression model is constructed as follows:

$$
\text { Gross Profit }=\beta_{0}+\beta_{1} \text { Marketing Exp. }+\beta_{2} R \& D \text { Exp. }+\varepsilon
$$

According to the Hausman (1978) test results, we should construct a random effect model, since the $p$ value $(0,8003)$ is higher than $5 \%$. Before interpret the model we have to check assumptions of panel data analysis. 
Test results of Levene (1960), Brown and Forsythe (1974) heteroscedasticity test shows that there is a heteroscedasticity problem in the model, since all the $p$ values are less than 5\%. To test serial correlation Baltagi-Wu (1999) LBI test and Adjusted Lagrange Multiplier test are performed. Baltagi-Wu (1999) LBI test statistic is lower than 2 and $p$-value of ALM test is lower than 0,05 . We can conclude that there is an autocorrelation problem in the model. Results of Pesaran's (2004) test of cross sectional independence shows that there is a cross sectional dependence problem in the model, since the probability is lower than 0,05.

In the model we fail to satisfy all the assumptions of panel regression analysis. Since we failed to satisfy all the assumptions, we have to interpret the regression model with Driscoll-Kraay (1998) standard errors estimators. The interpreted model results are summarized on the table below.

Table 2: Impact of Marketing and R\&D Expenditures on Gross Profit

\begin{tabular}{|c|c|c|c|c|}
\hline \multicolumn{5}{|c|}{ Regression with Driscoll-Kraay Standard Errors } \\
\hline \multicolumn{2}{|c|}{ Dependent Variable } & \multicolumn{3}{|l|}{ Gross Profit } \\
\hline \multicolumn{2}{|c|}{ Independent Variables } & \multicolumn{3}{|l|}{ Marketing, R\&D } \\
\hline \multicolumn{2}{|l|}{ Periods } & \multicolumn{3}{|c|}{ 2009-2015 (7 periods) } \\
\hline \multicolumn{2}{|c|}{ Number of Units } & \multicolumn{3}{|l|}{41} \\
\hline \multicolumn{2}{|l|}{ F Statistic } & \multicolumn{3}{|l|}{2419.40} \\
\hline \multicolumn{2}{|l|}{ Probability } & \multicolumn{3}{|l|}{0,0000} \\
\hline \multicolumn{2}{|l|}{ R square } & \multicolumn{3}{|l|}{0.8150} \\
\hline Variable & Coefficient & D-K Std. Err. & t statistic & p-value \\
\hline Constant & $1.05 e+08$ & $1.81 \mathrm{e}+07$ & 5.82 & 0,000 \\
\hline Marketing & 1.494459 & 0.0218431 & 68.42 & 0,000 \\
\hline$R \& D$ & 3.821826 & 0.2152653 & 17.75 & 0,000 \\
\hline
\end{tabular}

From the table above we can interpret the regression model. $\mathrm{F}$ statistic and its probability show that the model is valid. We can explain about $82 \%\left(R^{2}\right)$ of change in gross profit with marketing and $R \& D$ expenditures. All the independent variables are significant.

There is a positive impact of marketing and R\&D expenditures on firms' gross profit. 1 TL increase in marketing, increases operating income about 1,5 TL. $1 \mathrm{TL}$ increase in R\&D, increases revenue about 3,82 TL. Both marketing and R\&D expenditures increases gross profit of a firm in manufacturing sector. The impact of R\&D is higher than the impact of marketing on gross profit. This results show that marketing expenditures increases the sales and value of goods or/and service of a firm. Besides this, R\&D activities plays a very crucial role in increasing a firm's gross profit.

\subsection{Impact of Marketing and R\&D Expenditures on EBIT}

In this part the impact of marketing expenditures and research and development expenditures on earnings before interest and tax (EBIT) will be examined. There are many variables that affect EBIT and net income. In businesses there are mainly two ways to increase income; increasing revenue or/and decreasing costs. Instead of including revenue and cost of goods sold, which is the main cost in manufacturing industry, gross profit is included in the model as a control variable. Gross profit is found by deducting cost of goods sold from the revenue. Thus these two variables reduced to one variable. The regression model is constructed as follows:

$$
\text { EBIT }=\beta_{0}+\beta_{1} \text { Gross Profit }+\beta_{2} \text { Marketing Exp. }+\beta_{3} R \& D \text { Exp. }+\varepsilon
$$

According to the Hausman (1978) test results we will construct a random effect model, since the $p$ value $(0,2511)$ is higher than $5 \%$. We can test heteroscedasticity with Levene (1960), Brown and Forsythe (1974) test. According to the test results all the $p$ values are less than $5 \%$, thus we reject the null hypothesis. We conclude that, there is a heteroscedasticity problem in the model. To test autocorrelation Baltagi-Wu (1999) LBI test and Adjusted Lagrange Multiplier test are performed. Baltagi-Wu (1999) LBI test statistic is higher than 2 and p-value of ALM test is higher than 0,05 . We can conclude that there is no autocorrelation problem in the model. According to the results of Pesaran's (2004) test of cross sectional independence, probability is lower than 0,05 . We conclude that, there is a cross sectional dependence problem in the model.

In the model we fail to satisfy the assumptions of homoscedasticity and cross sectional independence and there is no autocorrelation in the model. We have to interpret the model with robust standard error estimators. We can interpret the 
regression model with Driscoll-Kraay (1998) standard errors estimators. The interpreted model results are summarized on the table below.

Table 3: Impact of Marketing and R\&D Expenditures on EBIT

\begin{tabular}{|c|c|c|c|c|}
\hline \multicolumn{5}{|c|}{ Regression with Driscoll-Kraay Standard Errors } \\
\hline \multicolumn{2}{|c|}{ Dependent Variable } & \multicolumn{3}{|c|}{ Earnings Before Interest and Tax } \\
\hline \multicolumn{2}{|c|}{ Independent Variables } & \multicolumn{3}{|c|}{ Gross Profit, Marketing, R\&D } \\
\hline \multicolumn{2}{|l|}{ Periods } & \multicolumn{3}{|c|}{ 2009-2015 (7 periods) } \\
\hline \multicolumn{2}{|c|}{ Number of Units } & \multicolumn{3}{|l|}{41} \\
\hline \multicolumn{2}{|l|}{ F Statistic } & \multicolumn{3}{|l|}{4841.23} \\
\hline \multicolumn{2}{|l|}{ Probability } & \multicolumn{3}{|l|}{0,0000} \\
\hline \multicolumn{2}{|c|}{ R square (overall) } & \multicolumn{3}{|l|}{0.9685} \\
\hline Variable & Coefficient & Robust Std. Err. & z statistic & p-value \\
\hline Constant & -2329207 & 3093244 & -0.75 & 0.451 \\
\hline Gross Profit & 0.9102994 & 0.0140564 & 64.76 & 0.000 \\
\hline Marketing & -1.031591 & 0.3472462 & -3.53 & 0,000 \\
\hline R\&D & -1.226139 & 2.257792 & 24.95 & 0,000 \\
\hline
\end{tabular}

From the table above we can interpret the regression model. F statistic and its probability show that the model is valid. We can explain about $97 \%\left(R^{2}\right)$ of change in earnings before interest and tax with gross profit, marketing and $R \& D$ expenditures. All the independent variables are significant.

We can see that there is a negative impact of marketing and R\&D expenditures on earnings before interest and tax (EBIT) of a firm in manufacturing industry. $1 \mathrm{TL}$ increase in gross profit, increases EBIT about 0,91 TL. $1 \mathrm{TL}$ increase in marketing, decreases EBIT about 1,03 TL. 1 TL increase in R\&D, decreases EBIT about 1,23 TL.

In an income statement EBIT is calculated as deducting all expenses, except tax and interest, from all earnings, except interest. Earning of a firm is driven mainly by sales. Main expenses of manufacturing companies are cost of goods sold and operating expenses. Operating expenses have three main items: general and administrative expenses, marketing expenses and research and development expenses. It is an expected situation that when a company increases its marketing and R\&D expenditures their EBIT will decreases with a same amount. However, these activities are supposed to increase manufacturing companies' profitability. Manufacturing companies seem to spend too much on marketing and R\&D activities and they cannot get enough profit in return. It seems that, manufacturing companies cannot use their marketing and R\&D budgets in an effective and efficient way.

\subsection{Impact of Marketing and R\&D Expenditures on Net Income}

In this part impact of marketing expenditures and research and development expenditures on net income will be examined. Gross profit is included in the model as a control variable. The regression model is constructed as follows:

$$
\text { Net Income }=\beta_{0}+\text { Gross Profit } \beta_{1}+\beta_{2} \text { Marketing Exp. }+\beta_{3} R \& D \text { Exp. }+\varepsilon
$$

According to Hausman (1978) test results we will construct a random effect model, since the $p$ value $(0,4069)$ is higher than $5 \%$. Before interpret the model we have to check assumptions of panel data analysis.

According to Levene (1960), Brown and Forsythe (1974) test of heteroscedasticity there is a heteroscedasticity problem in the model, since all the $p$ values are less than 0,05. To test serial correlation Baltagi-Wu (1999) LBI test and Adjusted Lagrange Multiplier test are performed. The results suggest that there is no autocorrelation problem in the model, since Baltagi-Wu (1999) LBI test statistic is higher than 2, and the probability of ALM test is greater than 0,05 . According to the results of Pesaran's (2004) CDLM and Friedman R (1937) tests of cross sectional independence there is no cross sectional dependence problem in the model, Since probability of two of the tests are higher than 0,05.

In the model we fail to satisfy homoscedasticity assumption. We have to interpret the model with Huber (1967), Eicker (1967) and White (1980) standard error estimators. However, since the significance level of the R\&D expenditures is 0,15 which is higher than 0,05, we can say that there is no impact of R\&D expenditures on net income. Since R\&D expenditures have no effect on net income, we have to exclude R\&D variable from the model and estimate the model again. The new regression model will be constructed as follows: 


$$
\text { Net Income }=\beta_{0}+\text { Gross Profit } \beta_{1}+\beta_{2} \text { Marketing Exp. }+\varepsilon
$$

According to Hausman (1978) test results we will construct a random effect model, since the $p$ value $(0,4731)$ is higher than $5 \%$. According to Levene (1960), Brown and Forsythe (1974) test of heteroscedasticity there is a heteroscedasticity problem in the model, since all the $p$ values are less than 0,05. To test serial correlation Baltagi-Wu (1999) LBI test and Adjusted Lagrange Multiplier test are performed. The results suggest that there is no autocorrelation problem in the model, since Baltagi-Wu (1999) LBI test statistic is higher than 2, and the probability of ALM test is greater than 0,05 According to the results of Pesaran's (2004) CDLM and Friedman R (1937) tests of cross sectional independence, we conclude that, there is no cross sectional dependence problem in the model, since the probability of two of the tests are higher than 0,05 .

As a consequence there is heteroscedasticity problem in the model, and there is no autocorrelation and cross sectional dependence problems. In the model we fail to satisfy homoscedasticity assumption of panel regression analysis. Since we failed to satisfy only the homoscedasticity assumption, we can interpret the model with Huber (1967), Eicker (1967) and White (1980) standard error estimators where the computed estimators are still consistent in the case of having heteroscedasticity problem. The interpreted model results are summarized on the table below.

Table 4: Impact of Marketing Expenditures on Net Income

\begin{tabular}{|c|c|c|c|c|}
\hline \multicolumn{5}{|c|}{ Regression with Huber, Eicker and White Standard Errors } \\
\hline \multicolumn{2}{|c|}{ Dependent Variable } & \multicolumn{3}{|l|}{ Net Income } \\
\hline \multicolumn{2}{|c|}{ Independent Variables } & \multicolumn{3}{|c|}{ Gross Profit, Marketing } \\
\hline \multicolumn{2}{|l|}{ Periods } & \multicolumn{3}{|c|}{ 2009-2015 (7 periods) } \\
\hline \multicolumn{2}{|c|}{ Number of Units } & \multicolumn{3}{|l|}{41} \\
\hline \multicolumn{2}{|c|}{ Wald $X^{2}$ Statistic } & \multicolumn{3}{|l|}{426.30} \\
\hline \multicolumn{2}{|l|}{ Probability } & \multicolumn{3}{|l|}{0,0000} \\
\hline \multicolumn{2}{|l|}{ R square } & \multicolumn{3}{|l|}{0.8614} \\
\hline Variable & Coefficient & Robust Std. Err. & z statistic & p-value \\
\hline Constant & -157704.5 & 8420005 & -0.02 & 0.985 \\
\hline Gross Profit & 0.6698096 & 0.032442 & 20.65 & 0,000 \\
\hline Marketing & -0.8618069 & 0.0522248 & -16.50 & 0,000 \\
\hline
\end{tabular}

Wald statistic and its probability show that the model is valid. We can explain about $86 \%\left(R^{2}\right)$ of change in net income with gross profit and marketing expenditures.

There is a negative impact of marketing expenditures on firms' net income and there is no impact of R\&D expenditures on firms' net income. 1 TL increase in gross profit, increases net income about 0,67 TL. 1 TL increase in marketing decreases net income about $0,86 \mathrm{TL}$. The impact of marketing on net income is negative in manufacturing sector. That is, when they increase their marketing expenditures, their net income decreases. The reason of this situation might be result ineffective usage of the marketing budget. Besides negative impact of the marketing expenditure, there is no impact of R\&D expenditures on the net income of a firm in manufacturing industry. Ineffective usage of marketing and R\&D budget may be a reason for these results.

\subsection{Impact of Marketing and R\&D Expenditures on Gross Profit Margin}

In this part it will be examined that how marketing expenditures and research and development (R\&D) expenditures affect gross profit margin (GPM). A static panel data model was constructed, but that model was not very explanatory as the model was not significant and the explanatory power of the model $\left(R^{2}\right)$ was very low. The reasons for that could be that the explanatory variables in the model were not adequate to explain the dependent variable which is GPM, or GPM may show a dynamic pattern. Thus a dynamic regression model will be constructed to investigate the impact of marketing and R\&D expenditures on GPM. The model will be constructed as below.

$$
G P M_{t}=\beta_{0}+\beta_{1} G P M_{t-1}+\beta_{2} \text { Marketing Exp }{ }_{t}+\beta_{3} R \& D \operatorname{Exp}_{t}+\varepsilon
$$

In order to make decision between fixed and random effect we have to run Hausman (1978) test. According to the results of Hausman (1978) test, the $p$ value $(0,0000)$ is lower than $5 \%$, thus we will construct a fixed effect model. The model is estimated as on the table below. 
Table 5: Impact of Marketing and R\&D Expenditures on Gross Profit Margin

\begin{tabular}{|c|c|c|c|c|}
\hline \multicolumn{5}{|c|}{ Fixed-effects (within) Regression } \\
\hline \multicolumn{2}{|c|}{ Dependent Variable } & \multicolumn{3}{|c|}{ Gross Profit Margin } \\
\hline \multicolumn{2}{|c|}{ Independent Variables } & \multicolumn{3}{|c|}{ GPM (1 lagged), Marketing, R\&D } \\
\hline \multicolumn{2}{|l|}{ Periods } & \multicolumn{3}{|c|}{ 2009-2015 (7 periods) } \\
\hline \multicolumn{2}{|c|}{ Number of Units } & \multicolumn{3}{|l|}{41} \\
\hline \multicolumn{2}{|l|}{ F Statistic } & \multicolumn{3}{|l|}{8.29} \\
\hline \multicolumn{2}{|l|}{ Probability } & \multicolumn{3}{|l|}{0.0000} \\
\hline \multicolumn{2}{|c|}{ R square (overall) } & \multicolumn{3}{|l|}{0.6349} \\
\hline Variable & Coefficient & Std. Err. & t statistic & p-value \\
\hline Constant & 0.149387 & 0.0138694 & 10.77 & 0.000 \\
\hline $\mathrm{GPM}_{\mathrm{t}-1}$ & 0.2858428 & 0.0635281 & 4.50 & 0.000 \\
\hline Marketing & $3.48 \mathrm{e}-11$ & $2.64 \mathrm{e}-11$ & 1.32 & 0.189 \\
\hline$R \& D$ & $1.19 e-10$ & $2.38 \mathrm{e}-10$ & 0.50 & 0.619 \\
\hline
\end{tabular}

From the table above we can see that the regression model is valid $(F=0,000)$. Explanatory power of the model is high enough $\left(R^{2}=63 \%\right)$. However there is no impact of Marketing and $R \& D$ expenditures on Gross Profit Margin.

GPM shows companies' ability to convert their sales into gross profit. The formula of GPM is shown below.

$$
\text { Gross Profit Margin }=\frac{(\text { Revenue }- \text { Cost of Goods Sold })}{\text { Revenue }}
$$

From the formula of GPM we can understand that if a company can control its cost of goods sold and sell their products for a higher and satisfied price, it can increase its gross profit margin. If a company can increase its gross profit it can also increase its GPM. High production costs will negatively affect and decrease GPM. Effective usage of raw materials, decreasing production costs and effective usage of other resources are key determinants for high and desirable GPM.

According to the tests results we can see that marketing and research and development expenditures make no contribution to manufacturing companies in converting their sales into gross profit. In shortly, marketing and research and development expenditures have no impact on manufacturing companies' GPM. Ineffective and inefficient allocation and usage of marketing and research and development budgets may be the reason for this results. Marketing and R\&D activities do not add sufficient and desirable value to their products.

\subsection{Impact of Marketing and R\&D Expenditures on Return on Sales}

In this part the impact of marketing expenditures and research and development expenditures affect return on sales (ROS) will be examined. A static panel data model was constructed, but that model was not very explanatory as the model was not significant and the explanatory power of the model $\left(R^{2}\right)$ was very low. The reasons for that could be that the explanatory variables in the model were not adequate to explain the dependent variable which is ROS, or ROS may show a dynamic pattern. Thus a dynamic regression model will be constructed to investigate the impact of marketing and R\&D expenditures on ROS. The regression model is constructed as follows:

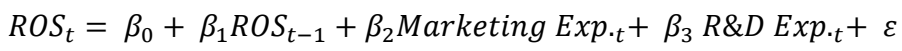

In order to make decision between fixed and random effect we have to run Hausman (1978) specification test. According to the results of Hausman (1978) test, the $p$ value $(0,0000)$ is lower than $5 \%$, thus we will construct a FE model .Estimation results are on the table below. 
Table 6: Impact of Marketing and R\&D Expenditures on Return on Sales

\begin{tabular}{|c|c|c|c|c|}
\hline \multicolumn{5}{|c|}{ Fixed-effects (within) Regression } \\
\hline \multicolumn{2}{|c|}{ Dependent Variable } & \multicolumn{3}{|c|}{ Return on Sales } \\
\hline \multicolumn{2}{|c|}{ Independent Variables } & \multicolumn{3}{|c|}{ ROS(1 lagged), Marketing, R\&D } \\
\hline \multicolumn{2}{|l|}{ Periods } & \multicolumn{3}{|c|}{ 2009-2015 (7 periods) } \\
\hline \multicolumn{2}{|c|}{ Number of Units } & \multicolumn{3}{|l|}{41} \\
\hline \multicolumn{2}{|l|}{ F Statistic } & \multicolumn{3}{|l|}{12.60} \\
\hline \multicolumn{2}{|l|}{ Probability } & \multicolumn{3}{|l|}{0.0000} \\
\hline \multicolumn{2}{|c|}{ R square (overall) } & \multicolumn{3}{|l|}{0.4633} \\
\hline Variable & Coefficient & Std. Err. & t statistic & p-value \\
\hline Constant & 0.0674094 & 0.0068395 & 9.86 & 0.000 \\
\hline $\operatorname{ROS}_{\mathrm{t}-1}$ & 0.3390443 & 0.0552475 & 6.14 & 0.000 \\
\hline Marketing & $1.18 \mathrm{e}-12$ & $3.21 \mathrm{e}-11$ & 0.04 & 0.971 \\
\hline$R \& D$ & $1.23 \mathrm{e}-10$ & $2.90 \mathrm{e}-10$ & 0.43 & 0.671 \\
\hline
\end{tabular}

From the table above we can see that the regression model is valid $(F=0,000)$. Explanatory power of the model is moderate $\left(R^{2}=46 \%\right)$. However, there is no impact of Marketing and $R \& D$ expenditures on Return on Sales in manufacturing industry.

ROS shows the companies' ability to convert their sales into profit and it is used to evaluate a company's operational efficiency. ROS is the percentage of total revenue which is converted into profit. ROS is calculated as dividing EBIT to revenue.

If a company can control its production cost and sell their products for a high price, it can increase its return on sales. Effective usage of resources and increasing income are key determinants for high and desired ROS. From the formula of ROS, we can say that if a company could increase its earnings before interest and tax through either decreasing expenses or increasing profit margin, company's ROS will increase.

According to this results, we can see that marketing and research and development expenditures make no contribution to manufacturing companies in converting their sales into profit. This means that, marketing and R\&D expenditures do not have impact on manufacturing companies' operational efficiency. It seems that manufacturing companies cannot use their marketing and research and development budgets in an efficient and effective way that these expenditures don't have any effect in their return on sales.

To sum up, according to the test results, there is a positive impact of marketing and research and development expenditures on revenue and gross profit in manufacturing industry. When manufacturing companies increases their marketing and R\&D expenditures they can increase their revenue and gross profit. Compare to marketing expenditures, $R \& D$ expenditures have more impact on revenue and gross profit.

There is a negative impact of marketing and research and development expenditures on earnings before interest and tax (EBIT) in manufacturing industry. When manufacturing companies increase their marketing and R\&D expenditures, it decreases their EBIT. EBIT includes operational incomes and operational expenses. Main operational expenses for a manufacturing company are cost of goods sold and operating expenses. Operating expenses have three main items: general administrative expenses, selling, distribution and marketing expenses and research and development expenses. Too much operating expenses decrease firms' EBIT. Manufacturing companies spend too much on marketing and R\&D activities that they cannot get enough income in return. That's why marketing and R\&D expenditures decrease manufacturing companies' EBIT. While there is no impact of R\&D expenditures on manufacturing companies' net income, there is a negative impact of marketing expenditures on net income.

Test results show us that there is no impact of marketing and research and development expenditures on gross profit margin (GPM) and return on sales (ROS) in manufacturing industry. In other words, marketing and R\&D activities do not make any contribution to manufacturing companies in converting their sales into profit. This shows us that marketing and R\&D budgets cannot be used in an effective and efficient way. 


\section{CONCLUSION}

In this research we examined the impact of "Marketing" and "Research and Development" expenditures on firms' financial performance in manufacturing industry. As a financial performance indicators "Revenue", "Gross Profit", "Earnings Before Interest and Tax (EBIT)", "Net Income", "Gross Profit Margin (GPM)" and "Return on Sales (ROS)" were selected. Impact of marketing and R\&D expenditures on these financial performance indicators were examined separately. The sample was consist of 41 manufacturing company listed on Borsa Istanbul, which have done marketing and R\&D activities regularly. Yearly data was gathered for the period of 2009-20015 from these companies' financial statements. The data set was a panel data with 41 units and 7 periods. In order to analyze the impact of marketing and R\&D expenditures on selected financial performance indicators methods of panel data regression were performed and panel data regression models were constructed.

The ultimate aim of marketing and R\&D activities are gaining competitive advantage and increase financial performance. Test results imply that marketing and R\&D expenditures have positive contribution to manufacturing companies' some of the financial performance indicators. However, manufacturing companies cannot use marketing and R\&D budgets in an effective and efficient way. Manufacturing companies are not able to manage marketing and R\&D activities successfully, since expenditures related with these activities have no contribution in converting their sales into profit and even decrease their earnings.

There were 193 manufacturing companies listed on Borsa Istanbul by 2015. All of them carry on marketing activities and have related expenditures. However, only 41 of them, which is about $21 \%$, do regular research and manufacturing expenditures since 2009. Even this situation shows that manufacturing companies don't attach enough importance to R\&D activities, although we know that producing and offering innovative and superior products, which is output of R\&D activities, are main sources of financial stability and growth in manufacturing industries.

Manufacturing companies seem not to allocate and use their marketing and R\&D budgets in effective and efficient way, by which they could increase their profitability. It is clear that, there is a lack of effective management and control of marketing and R\&D activities in manufacturing industry. In order to increase financial performance, increase business value, create value for stakeholders and gain sustainable competitive advantage, management of manufacturing companies must control and manage marketing and research and development activities and processes more effectively and efficiently. It is obvious that, efficient and effective implementation of marketing and R\&D activities will provide companies with sustainable competitive advantage and they can increase their profitability and financial performance.

\section{ACKNOWLEDGEMENTS}

This study is a part of the Master dissertation by Mehmet Çağlar.

\section{REFERENCES}

Aaker, D. A., \& Jacobson, R. 1994. "The financial information content of perceived quality", Journal of Marketing Research, vol. 31, no. 2, pp. 191-201.

Andras, T. L., \& Srinivasan, S. S. 2003. “Advertising Intensity And R\&D Intensity: Differences across Industries and Their Impact on Firm's Performance", International Journal of Business and Economics, vol. 2, no. 2, pp. 167-176.

Artz, K. W., Norman, P. M., Hatfield, D. E., \& Cardinal, L. B. 2010. "A longitudinal study of the impact of R\&D, patents, and product innovation on firm performance", Journal of Product Innovation Management, vol. 27, no. 5, pp. 725-740.

Baltagi, B. H., \& Wu, P. X. 1999. “Unequally Spaced Panel Data Regressions with AR (1) Disturbances”, Econometric Theory, vol. 15, no. 6, pp. 814-823.

Bettis, R. A., \& Hitt, M. A. 1995. “The new competitive landscape”, Strategic Management Journal, vol. 16, no. S1, pp. 7-19.

Bhargava, A., Franzini, L., \& Narendranathan, W. 1982. "Serial Correlation and the Fixed Effects Model", The Review of Economic Studies, vol. 49, no. 4, pp. 533-549.

Bowen, F. E., Rostami, M., \& Steel, P. 2010. "Timing is everything: A meta-analysis of the relationships between organizational performance and innovation", Journal of Business Research, vol. 63, no. 11, pp. 1179-1185

Brown, M. B., \& Forsythe, A. B. (1974). "Robust tests for the equality of variances". Journal of the American Statistical Association, 69(346), 364-367.

Cohen, W. M., \& Levinthal, D. A. 1989. “Innovation and learning: The two faces of R\&D” The Economical Journal, vol. 99, no. 397, pp. 569596 
Danneels, E., \& Kleinschmidt, E. J. 2001. “Product innovativeness from the firm's perspective: Its dimensions and their relation with project selection and performance", Journal of Product Innovation Management, vol. 18, no. 6, pp. 357-373

Day, G. S. 1994. “The capabilities of market-driven organizations”, Journal of Marketing, vol. 58, no. 1, pp. 37-52.

De Luca, L. M., \& Atuahene-Gima, K. 2007. "Market knowledge dimensions and crossfunctional collaboration: Examining the different routes to product innovation performance", Journal of Marketing, vol. 71 no. 1, pp. 95-112.

Driscoll, J., and A. C. Kraay. 1998. "Consistent Covariance Matrix Estimation with Spatially Dependent Data", Review of Economics and Statistics, vol. 80 no. 4, pp. 549-560.

Dutta, S., Narashiman, O., \& Surendra, R. 1999. "Success in high technology markets: Is marketing capability critical?", Marketing Science, vol. 18 , no. 4, pp. 547-568.

Edvinsson, L., \& Malone, M. S. 1997. "Intellectual Capital: Realizing Your Company's True Value by Finding Its Hidden Brainpower".

Eicker, F. (1967), "Limit Theorems for Regressions with Unequal and Dependent Errors," Proceedings of the Fifth Berkeley Symposium on Mathematical Statistics and Probability 1, 59-82. Berkeley: University of California Press.

Frees, E. W. 1995. "Assessing Cross-Sectional Correlation in Panel Data", Journal of Econometrics, vol. 69, no. 2, pp. 393-414.

Friedman, M. (1937). "The Use of Ranks to Avoid the Assumption of Normality Implicit in the Analysis Of Variance", Journal of The American Statistical Association, 32(200), 675-701.

Gupta, A. K., Raj, S., \& Wilemon, D. 1986. "A model for studying R\&D - Marketing Interface in the product innovation process", Journal of Marketing, vol. 50, no. 2, pp. 7-17.

Hausman, J. A. 1978. "Specification Tests in Econometrics", Econometrica, vol. 46, no. 6, pp. 1251-1271.

Helfat, C. E., \& Peteraf, M. A. 2003. "The dynamic resource-based view: Capability lifecycles", Strategic Management Journal, vol. 24, no. 10, pp. 997-1010.

Hsu, F. J., Chen, M. Y., Chen, Y. C., \& Wang, W. C. 2013. "An empirical study on the relationship between R\&D and financial performance", Journal of Applied Finance and Banking, vol. 3, no. 5, pp. 107-119

Huber, P. J. (1967), "The Behavior of Maximum Likelihood Estimates under Nonstandard Conditions," in Proceedings of the Fifth Berkeley Symposium in Mathematical Statistics, Volume 1. Berkeley: University of California Press, 221-233.

Krasnikov, A., \& Jayachandran, S. 2008. "The Relative Impact of Marketing, Research-And-Development, and Operations Capabilities on Firm Performance", Journal of Marketing, vol. 72, no. 4, pp. 1-11.

Lantz, J. S., \& Sahut, J. M. 2005. "R\&D investment and the financial performance of technological firms", International Journal of Business, vol. 10 , no. 3, pp. 251-270.

Levene, H. (1960). "Robust tests for equality of variances". Contributions to Probability and Statistics, 1, 278-292.

Liao, T. S., \& Rice, J. 2010. "Innovation investments, market engagement and financial performance: A study among Australian manufacturing SMEs", Research Policy, vol. 39, no.1, pp. 117-125

Lynn, G. S. 1998. "New product team learning: Developing and profiting from your knowledge”, California Management Review, vol. 3, no. 38, pp. 74-93.

Mizik, N., \& Jacobson, R. 2003. "Trading off between Value Creation and Value Appropriation: The Financial Implications of Shifts in Strategic Emphasis", Journal of Marketing, vol. 67, no. 1, pp. 63-76.

Narsimhan, O., Rajiv, S., \& Dutta, S. 2006. "Absorptive capacity in high technology markets: The competitive advantage of the haves", Marketing Science, vol. 25, no. 5, pp. 510-524

Nath, P., Nacchiapan, S., \& Ramanathan, R. 2010. "The impact of marketing capability, operations capability and diversification strategy on performance: A resource-based view”, Industrial Marketing Management, vol. 39, no. 2, pp. 307-329

Ortega, M. J. R., \& Villaverde, P.M. G. 2008. “Capabilities and competitive tactics influences on performance: Implications of the moment of entry", Journal of Business Research, vol. 61, no. 4, pp. 332-345

O'Sullivan, D., \& Abela, A. V. 2007. “Marketing Performance Measurement Ability and Firm Performance”, Journal of Marketing, vol. 71, no. 2, pp. 79-93.

Pesaran, M. H. 2003. "A Simple Panel Unit Root Test in The Presence of Cross-Section Dependence", Cambridge Working Papers in Economics, 0346, pp. 1-24.

Pesaran, M. H. (2004). "General Diagnostic Tests for Cross Section Dependence in Panels", University of Cambridge, Faculty of Economics, Cambridge Working Papers in Economics No. 0435.

Peterson, R. A., \& Jeong, J. 2010. "Exploring the Impact of Advertising and R\&D Expenditures on Corporate Brand Value and Firm-Level Financial Performance", Journal of the Academy of Marketing Science, vol. 38, no. 6, pp. 677-690. 
Ramaswami, S., Srivastava, R., \& Bhargava, M. 2009. “Market-based capabilities and financial capabilities of firms: insights into marketing's contribution to firm value", Journal of the Academy of Marketing Science, vol. 37, no. 2, pp. 97-116.

Ruiqi, W., Wang, F., Xu, L., \& Yuan, C. 2017. "R\&D expenditures, ultimate ownership and future performance: Evidence from China", Journal of Business Research, vol. 71, pp. 47-54.

Sharp, B. 1996. "Brand equity and market-based assets of professional service firms", Journal of Professional Services Marketing, vol. 13, no. 1 , pp. 3-13.

Slotegraaf, R. J., \& Pauwels, K. 2008. "The impact of brand equity and innovation on the long-term effectiveness of promotions", Journal of Marketing Research, vol. 45, no. 3, pp. 293-306.

Song, M., Benedetto, A.D., \& Nason, R. W. 2007. "Capabilities and financial performance: The moderating effect of strategic type", Journal of the Academy of Marketing Science, vol. 35, no. 1, pp. 18-34.

Song, M., Droge, C., Hanvanich, S., \& Calantone, R. 2005. "Marketing and technology resource complementarity: An analysis of their interaction effect in two environmental contexts", Strategic Management Journal, vol. 26, no. 3, pp. 259-276

Srinivasan, S., \& Hanssens, D. M. 2009. "Marketing and Firm Value: Metrics, Methods, Findings, and Future Directions", Journal of Marketing Research, vol. 46, no. 3, pp. 293-312.

Srivastava, R. K., Shervani, T. A., \& Fahey, L. 1998. "Market-based assets and shareholder value: A framework for analysis", The Journal of Marketing, vol. 62, no. 1, pp. 2-18.

Treacy, M., \& Wiersema, F. 1993. “Customer Intimacy and Other Value Disciplines”, Harvard Business Review, vol. 71, no.1, pp. 84-93.

Vorhies, D. W., \& Morgan, N. A. 2003. "A configuration theory assessment of marketing organization fit with business strategy and its relationship with marketing performance", Journal of Marketing, vol. 67, no. 1, pp. 100-115.

Vorhies, D. W., \& Morgan, N. A. 2005. "Benchmarking marketing capabilities for sustained competitive advantage”, Journal of Marketing, vol. 69 , no. 1 , pp. 80-94

Voss, C. A. 1994. "Significant issues for the future of product innovation" Journal of Product Innovation Management, vol. 11, no. 5, pp. 460-463.

White, H. (1980), “A Heteroscedasticity-Consistent Covariance Matrix Estimator and a Direct Test for Heteroscedasticity," Econometrica 48, 817-838.

Yu, W., Ramanathan, R., \& Nath, P. 2014. "The Impacts Of Marketing And Operations Capabilities On Financial Performance In the Uk Retail Sector: A Resource-Based Perspective", Industrial Marketing Management, Vol. 43, No. 1, PP. 2 